\title{
On Robust Alternate Possibilities and the Tax Evasion Case
}

William Simkulet

Cleveland State University, w.simkulet@csuohio.edu

Follow this and additional works at: https://engagedscholarship.csuohio.edu/clphil_facpub

Part of the Philosophy Commons

How does access to this work benefit you? Let us know!

\section{Publisher's Statement}

This article first appeared in Southwest Philosophy Review, Volume 31, Issue 1, 2015, 101-107.

https://www.pdcnet.org/pdc/bvdb.nsf/

purchase?openform\&fp=swphilreview\&id=swphilreview_2015_0031_0001_0101_0107

\section{Repository Citation}

Simkulet, William, "On Robust Alternate Possibilities and the Tax Evasion Case" (2015). Philosophy \& Comparative Religion Department Faculty Publications. 21.

https://engagedscholarship.csuohio.edu/clphil_facpub/21

This Article is brought to you for free and open access by the Philosophy \& Comparative Religion Department at EngagedScholarship@CSU. It has been accepted for inclusion in Philosophy \& Comparative Religion Department Faculty Publications by an authorized administrator of EngagedScholarship@CSU. For more information, please contact library.es@csuohio.edu. 


\title{
On Robust Alternate Possibilities and the Tax Evasion Case
}

\author{
William Simkulet \\ University of Wisconsin - Marshfield/Wood County
}

Abstract: In his recent article "Defending Hard Incompatibilism Again," Pereboom (2008) presents what he calls the "Tax Evasion" case, a Frankfurt-style case designed to show the falsity of the principle of alternate possibilities (PAP). According to Pereboom, PAP requires robust alternate possibilities such that an agent could have acted in a manner in which she knew she would have lacked moral responsibility for her actions. However, according to his "Tax Evasion" case, the tax evader lacks such robust alternate possibilities, and yet is still uncontroversially morally responsible for his actions. Here I argue Pereboom's account of robust alternate possibilities is deficient, offer a more intuitively plausible account of robust alternate possibilities, and argue that Pereboom's tax evasion case fails to cut off morally relevant alternate possibilities.

In "Alternate Possibilities and Moral Responsibility," Harry Frankfurt (1969) presents an infamous case designed to be a counterexample to the principle of alternate possibilities (PAP). According to PAP moral responsibility requires the ability to have done otherwise-To be morally responsible for some action $x$, you must have been able to do something other than $x$.

In a Frankfurt-style case an agent is said to lack alternate possibilities, yet be uncontroversially morally culpable for her actions. Critics of Frankfurt argue that such cases fail to prove the falsity of PAP-either such cases fail to cut off alternate possibilities, or the agents involved aren't uncontroversially morally responsible for acting (see Kane, 1985; 1996; Widerker, 1995; Ginet, 1996; and Goetz, 2005).

Pereboom argues that PAP requires more than just alternate possibilities - it requires robust alternate possibilities, and constructs a case in which he believes an agent is uncontroversially morally responsible despite lacking this kind of alternate possibilities (see Pereboom, 2005; 2008). In this paper I argue that Pereboom's account of robust alternate possibilities is at odds with our moral intuitions, propose an alternate account of robustness, and then argue his case fails to cut off this relevant form of alternate possibilities. 
Frankfurt-style cases are attempts to demonstrate the falsity of PAP by showing that an agent can be uncontroversially morally responsible despite lacking the ability to do otherwise. ${ }^{1}$ Unfortunately for proponents of such cases, they fail. Critics have successfully shown that in these cases either the case-designer needs to assume universal causal determinism, which undermines our moral intuitions about the guilt of the agent, or it fails to cut off alternate possibilities. ${ }^{2}$

John Martin Fischer contends that although Frankfurt cases fail to cut off all alternate possibilities, the available alternate possibilities are "insufficiently robust to ground our attributions of moral responsibility" (1999, p. 210). Pereboom offers the following account of robustness:

\begin{abstract}
Robustness (2): For an alternative possibility to be relevant to explaining why an agent is morally responsible for an action it must satisfy the following characterization: she could have willed something different from what she actually willed such that she understood that by willing it she would be, or at least would likely to be, precluded from the responsibility she actually has. (2008, pp. 7-8)
\end{abstract}

To have had robust alternate possibilities, according to Pereboom, is to have been such that (i) you could have acted other than you actually acted and (ii) had you acted in this fashion, you would have been differently morally responsible. Pereboom's account does not, however, require that one have had the opportunity to be entirely precluded from moral responsibility, rather he only requires that one had the opportunity to be responsible for a different thing. Strictly speaking, Pereboom's account of robust alternate possibilities is consistent with all of an agent's possible actions being such that she would be blameworthy for choosing any of them. However, this account is seriously at odds with our commonsense moral intuitions.

A more charitable reading of Pereboom's account of robustness includes a third criteria-Avoidability of moral responsibility. This account of robustness is best read as derived from Michael Otsuka's principle of avoidable blame. In "Incompatibilism and the Avoidability of Blame," Otsuka (1998) constructs an alternate principle to PAP-the principle of avoidable blame (PAB), according to which for an agent to be morally blameworthy for her actions, she must have been able to act in a manner in which she would have been entirely morally blameless. This is not to say that had she acted differently she would be entirely precluded from moral responsibility; rather her alternate actions might 
have been praiseworthy, or at least morally acceptable. ${ }^{3}$ Like PAP, PAB requires alternate possibilities, only more narrowly construed. Shortly after unveiling his original account of robustness in "Defending Hard Incompatibilism," Pereboom (2005) cites Otsuka, so it is safe to assume he had Otsuka's principle in mind. ${ }^{4}$

According to PAB, to be blameworthy one must be able to act in a manner in which one is entirely blameless, not entirely deficient of moral responsibility. We can construct a similar principle concerning praiseworthiness - what I call the principle of avoidable praise or acclaim (PAA, for abbreviation clarity), according to which praiseworthiness requires that one have the ability to act in a manner in which one entirely morally praiseless. (Such an action may be blameworthy or merely acceptable, but not worthy of praise.) Pereboom is best understood as having the following account of robustness:

An alternate possibility is robust if and only if the action satisfies the following characterization: If the agent is blameworthy, she must have had the ability to act in a manner in which she would be entirely morally praiseless. If the agent is praiseworthy, she must have had the ability to act in a manner in which she would be entirely morally blameless.

The problem here is that Pereboom has effectively substituted PAB (and PAA) for PAP, a much less robust principle. While both PAB and PAA are intuitively compelling, they are perhaps a bit too specific for Frankfurtstyle cases, which are designed to demonstrate the falsity of any reasonable account of PAP. As such, I think the following account of robustness is an appropriate target for Frankfurt-style cases:

An agent has a robust alternate possibilities if and only if she could have acted in a manner in which she believes ${ }^{5}$ she would have been differently morally responsible.

This account of robustness is consistent with Fischer's criticism that a twitch doesn't satisfy a sufficiently robust alternate possibility, but is also consistent with Otsuka's assertion that persons in traditional Frankfurtstyle cases have avoidable blame. As such, if Pereboom's case can show an agent lacks robust alternate possibilities of this kind, he will have successfully demonstrated the falsity of PAP, PAB, and PAA. 
Here is a concise version of Pereboom's "Tax Evasion" case:

Joe has good reason to believe that he can get away with cheating on his taxes, but believes it is wrong to do so. His strong desire to advance his own self interest will causally determine Joe to cheat on his taxes at time $t 1$, unless he exercises his libertarian free will to choose otherwise. Joe cannot change his mind on a whim.

In order to exercise his libertarian free will, Joe must first reach a certain level of attentiveness to moral reasons, and Joe can do so voluntarily. However, even if he reaches this level of attentiveness, and exercises his libertarian free will, his libertarian free will can result in him choosing either to pay his taxes in full, or to cheat on his taxes.

A neuroscientist has, unbeknownst to Joe, implanted a device in his brain which is triggered by him reaching the appropriate level of moral attentiveness. When triggered, the device robs him of his libertarian free will and causally determines him to cheat on his taxes. As it so happens, Joe never raises his moral attentiveness level "and he chooses to evade taxes on his own, while the device remains idle." (Pereboom, 2008, pp. 9-10)

Pereboom contends that (A) Joe lacks robust alternate possibilities, and yet $(\mathrm{B})$ he is uncontroversially morally responsible for cheating on his taxes. Either (A) or (B) is false.

Perhaps the most glaring issue with the tax evasion case is the utterly bizarre decision making process Pereboom saddles Joe with. Joe can't act on a whim - for example, he can't wake up one night and, on a whim, choose to complete his taxes. Rather, the only way for Joe to do what he believes is morally correct is to first jump through the hoop of "raising his moral attentiveness level," and only after doing this does he have the ability to exercise his libertarian free will regarding his choice to pay his taxes.

Joe is nothing like we think we are. We believe that we can act on a whim (whether this belief is justified is outside the scope of this paper), and thus it's not at all clear that we can trust our moral intuitions about this case even if we're inclined to agree that Joe is morally culpable for cheating on his taxes in this case.

However, let us assume that if Joe raised his moral attentiveness level, and had there been no device to circumvent his libertarian free will, then Joe would have been uncontroversially morally responsible for his 
actions. Now let us turn our attention to the steps that Joe must engage in to make a free choice about his taxes - according to Pereboom, Joe must first voluntarily raise his moral attentiveness level. How does this occur? There are several possibilities. His raising his moral attentiveness level might be (i) completely causally determined by circumstances outside of his control, (ii) causally determined by an indeterministic decision making method outside of his control, or (iii) causally determined by his libertarian free will. If (i) or (ii), then according to most of us it doesn't make sense to hold Joe morally accountable for cheating on his taxes because there was nothing he could do to avoid this, and thus (B) would be false- Joe is not uncontroversially morally responsible for his actions. ${ }^{6}$ In fact, quite the opposite, Joe is uncontroversially not responsible for what he is forced to do.

Suppose, though, that raising his moral attentiveness level was a matter of his exercising his libertarian free will - either (iiia) Joe was aware of reasons he ought to utilize his libertarian free will to raise his moral attentiveness level, or (iiib) he wasn't. Joe's decision making process is prima facie unlike ours, and it's not at all clear that Joe is aware of how his decision making process works. If (iiib) then he doesn't know that a prerequisite for choosing to pay his taxes is to first raise his moral attentiveness level and it doesn't make sense to blame him for failing to do something he didn't have any reason to do-again (B) would be false.

However, if (iiia), then Joe believes that a necessary, but not sufficient, step for his choosing not to cheat on his taxes is for him to first utilize his libertarian free will to raise his moral attentiveness level. By failing to use his libertarian free will to raise his moral attentiveness level, he is setting himself up for future moral failure. If one has a moral obligation to do $x$, then one has a moral obligation to do all the steps necessary to achieve $x$. When Joe fails to raise his attentiveness, he fails to do a step necessary to achieve his obligation to pay his taxes, and as such he is uncontroversially blameworthy for this failure independently of whether or not he could have chosen to cheat on his taxes later on. If (iiia), then Joe had robust alternate possibilities because he could have acted in a way in which he believed he would have been differently morally responsibly. This is to say that (A) is false.

In summation, Pereboom contends that Joe lacks robust alternate possibilities, and yet he is uncontroversially morally responsible for choosing to cheat on his taxes. Pereboom stipulates that a necessary, but not sufficient, condition for Joe to pay his taxes is that he must first do something else-raise his moral attentiveness level (whatever this is). Either it is in Joe's control to do this, or it is not. If it's not within 
Joe's control, intuitively he's not morally responsible for failing to do so or summarily being causally determined to cheat on his taxes as result. Suppose, though, that it is within Joe's control to raise his attentiveness, and furthermore that Joe knows that raising his attentiveness is a necessary step to doing the right thing. If this were the case, then Joe can either freely choose to raise his attentiveness level or not. If Joe has a moral obligation to pay his taxes, then he has a moral obligation to do everything necessary to pay his taxes. Thus, Joe can either satisfy his moral obligation to raise his attentiveness level and be prima facie praiseworthy for doing so, or fail to do so and be prima facie blameworthy; but this just is to say that Joe has robust alternate possibilities - Joe can act in a manner in which he believes he will be differently morally responsible than if he fails to act in that manner.

\section{Notes}

1 See Frankfurt (1969), Mele and Robb (1998), and Fischer (2010) for traditional Frankfurt-style cases designed to show the agent lacks any alternate possibilities.

2 Recently Harry Frankfurt has taken the position that his original case doesn't cut off alternate possibilities, but supposedly shows that alternate possibilities play no role in determining the agent's responsibility—see Frankfurt (2003/2006).

3 It is outside the scope of this paper whether it is possible to be morally responsible, but neither praiseworthy or blameworthy, or what this would be like, but if such a state is possible, it would satisfy the alternate possibilities required by PAB.

4 Pereboom's first account of robustness can be found in his (2005, p. 232), and cites Otsuka three pages later.

5 There is room to debate whether this belief needs to be justified, or whether strong but irrational belief is sufficient, but this discussion is outside the scope of this paper.

6 At least there's nothing Joe can do during the events described in the case, he might be morally responsible for coming to have a selfish character, or for having previously freely chosen to cheat on his taxes.

\section{Works Cited}

Fischer, John Martin. (1999) Recent Work on Moral Responsibility. Ethics 110: 93-139.

- (2010) The Frankfurt Cases: The Moral of the Stories. Philosophical Review 119: 315-336.

Frankfurt, Harry G. (1969) Alternate Possibilities and Moral Responsibility. The Journal of Philosophy 66(23): 829-839. 
. (2003/2006) Some Thoughts Concerning PAP. In David Widerker and Michael McKenna (eds.), Moral Responsibility and Alternative Possibilities Essays on the Importance of Alternative Possibilities (pp. 339-345). Burlington: Ashgate Publishing Company.

Ginet, Carl. (1996) In Defense of the Principle of Alternative Possibilities: Why I Don't Find Frankfurt's Argument Convincing. Philosophical Perspectives 10: 403-417.

Goetz, Stewart. (2005) Frankfurt-Style Counterexamples and Begging the Question. Midwest Studies in Philosophy 29: 83-105.

Kane, Robert. (1985) Free Will and Values. Albany: State University of New York Press.

- (1996) The Significance of Free Will. New York: Oxford University Press.

Mele, Alfred R. and David Robb. (1998) Rescuing Frankfurt-Style Cases. The Philosophical Review 107(1): 97-112.

Otsuka, Michael. (1998) Incompatibilism and the Avoidability of Blame. Ethics 108(4): 685-701.

Pereboom, Derk. (2005) Defending Hard Incompatibilism. Midwest Studies 29: 228-247.

- (2008) Defending Hard Incompatibilism Again. In Nick Trakakis and Daniel Cohen (eds.), Essays on Free Will and Moral Responsibility (pp. 1-33). Newcastle-upon-Tyne: Cambridge Scholars Press.

Widerker, David. (1995) Libertarianism and Frankfurt's Attack on the Principle of Alternative Possibilities. Philosophical Review 104: 247-61.

Pre-print standardized by MSL Academic Endeavors, the imprint of the Michael Schwartz Library at Cleveland State University, 2015 